\title{
Serum Ferritin and Iron Status of Mothers and Newborns in Lubumbashi in the DRC
}

\author{
A. Yaba ${ }^{*}$, T. M. J. Ngwe' ${ }^{2}$, Y. N. Assumani', K. H. Tamubango ${ }^{3}$, M. K. P. Kalenga ${ }^{2}$, M. A. Mutombo4, \\ E. Ghini ${ }^{5}$, 0. S. Wembonyama1, N. O. Luboya ${ }^{1}$
}

\begin{abstract}
${ }^{1}$ Department of Pediatrics, Faculty of Medicine, University of Lubumbashi, Lubumbashi, Democratic Republic of the Congo ${ }^{2}$ Department of Gynecology-Obstetrics, Faculty of Medicine, University of Lubumbashi, Lubumbashi, Democratic Republic of the Congo ${ }^{3}$ Department of Public Health Mother and Child, High Institute of Medical Technics, Likasi, Democratic Republic of the Congo ${ }^{4}$ Department of Pediatrics, Faculty of Medicine, Official University of Mbujimayi, Mbujimayi, Democratic Republic of the Congo ${ }^{5}$ Department of Pediatrics, Faculty of Medicine, University of Kinshasa, Kinshasa, Democratic Republic of the Congo Email: *docteuryaba@gmail.com
\end{abstract}

How to cite this paper: Yaba, A., Ngwe, T.M.J., Assumani, Y.N., Tamubango, K.H., Kalenga, M.K.P., Mutombo, M.A., Ghini, E., Wembonyama, O.S. and Luboya, N.O. (2020) Serum Ferritin and Iron Status of Mothers and Newborns in Lubumbashi in the DRC. Open Access Library Journal, 7: e6869.

https://doi.org/10.4236/oalib.1106869

Received: September 27, 2020

Accepted: November 24, 2020

Published: November 27, 2020

Copyright $\odot 2020$ by author(s) and Open Access Library Inc.

This work is licensed under the Creative Commons Attribution International License (CC BY 4.0).

http://creativecommons.org/licenses/by/4.0/

(c) (i) Open Access

\begin{abstract}
Introduction: Ferritin is the primary form of intracellular iron storage. The serum concentration generally gives a faithful reflection of the level of iron reserves in the body. Hyperferritinemia is an early and specific marker of iron deficiency. Methodology: A descriptive cross-sectional study with an analytical component was carried out in DR Congo in order to determine the reference values of serum ferritin for mother-newborn couples and to establish the link between these values in mothers and their newborns. Mothers who delivered at term after a singleton pregnancy with no history of breakthrough bleeding or blood transfusion and eutrophic newborns with good APGAR showing no pathology, neither malformation, were included in the study. A blood sample was taken from the mother and the newborn for the determination of ferritin and CRP (C-reactive protein) and certain elements of the hemogram according to the methods recommended by the IFCC (International Federation of Clinical Chemistry) and ICSH (International Council for Standardization in Hematology). We have coupled the ferritin assay to CRP in order to eliminate cases of inflammatory syndrome that can influence ferritinemia. Iron supplementation and consumption of kaolin and tea during pregnancy, and some sociodemographic parameters of mothers and newborns were studied. Results: A total of 103 mother-newborn couples were selected. For mothers: the average age was $27.68 \pm 6.42$ years and the average parity was $3.80 \pm 2.52$. About $98.06 \%$ lived as a couple, $78.64 \%$ had a secondary education, $51.48 \%$ engaged in a revenue-generating activity and $20.40 \%$ had a poor nutritional status. Regarding the sex of the newborn, $56.3 \%$ were female. The mean serum ferritin level of the mothers is $59.21 \pm 48.09 \mu \mathrm{g} / \mathrm{l}$ with a variability of 81.22 ; while it is $290.18 \pm 212.69 \mu \mathrm{g} / \mathrm{l}$ with a variability of
\end{abstract}


73.29 in newborns. Reference values of serum ferritin ranged from 21.10 to $114.00 \mu \mathrm{g} / \mathrm{l}$ in mothers and 60.99 to $749.01 \mu \mathrm{g} / \mathrm{l}$ in newborns. There is a positive and significant correlation in the mothers between the hemoglobin level and the CCMH $(0.216$ and $\mathrm{p}=0.029)$ and between the reticulocytes and the CCMH $(0.270$ and $p=0.006)$. In newborns, there is a positive and significant correlation between hemoglobin and ferritin $(\mathrm{r}=0.288 ; \mathrm{p}=0.003)$ and between hemoglobin and TCCM $(0.191$ and $p=0.037)$. We found a positive and significant correlation between maternal ferritin and the newborn VGM $(0.191$ and $p=0.037)$. Iron Supplementation during pregnancy causes significant increase of hemoglobin in the newborn $(\mathrm{p}=0.020)$. While the consumption of tea and Kaolin during pregnancy although statistically insignificant tends to decrease the values of hemoglobin, VGM, CCMH, reticulocytes and ferritin in newborns. Conclusion: The mother-newborn Lubumbashi has a rate of ferritin serum in usual standards. To better understand the origins-deficiency anemia of the newborn within 24 hours of birth in our midst, we propose that we consider as reference values of ferritin in serum, those in the range [60.99 - $749.01 \mu \mathrm{g} / \mathrm{l}]$. Although small and not statistically significant, there is a relationship of negative correlation between ferritin maternal serum and the newborn.

\section{Subject Areas}

Gynecology \& Obstetrics, Pediatrics

\section{Keywords}

Ferritin Serum, Iron Status, Mother-Newborn Couple, Lubumbashi, DRC

\section{Introduction}

Ferritin is the primary form of intracellular iron storage. It is a hollow protein sphere of approximately $12 \mathrm{~nm}$ in diameter and with a molecular mass of $440,000 \mathrm{~g} / \mathrm{mol}$ [1]. It occupies a primordial place in the evaluation of iron status since its serum concentration generally gives a faithful reflection of the level of iron reserves in the body. The hypo ferritin is an early and specific marker of iron deficiency [2] [3], the dosage of serum iron is a poor indicator for assessing iron deficiency anemia because often influenced by the circadian rhythm using ferritin assay [4] [5].

From childhood, this parameter undergoes major pathophysiological changes related to a particular increase of iron requirements, to an intake deficiency sometimes relationship with socio-economic problems. This pediatric population is therefore a significant risk of developing iron deficiency [5] [6]. These iron deficiencies have significant hematological, but also extra hematological repercussions, in particular on cognitive functions and on immunity [7] [8].

In Africa, the iron deficit remains the leading cause of anemia responsible for a high infant and child mortality risk [9]. In 2012, a WHO study reported that 
iron deficiency is a common form of nutritional deficiency in children; it results from a prolonged imbalance in the iron balance, which is due to an insufficient supply of iron, a problem of absorption or use of iron, increased needs for iron during the period of growth or losses of blood caused by parasitic infections (malaria, helminthiasis and schistosomiasis) [10].

In the DRC, Kalenga et al. in 2002 reported $51.77 \%$ prevalence of anemia among children aged 1 to 2 years which they said was linked to malaria and nutritional deficiencies [11]. Recently, the EDS-DRC II (2014) reported that in the DRC nearly one in two children aged 6 to 59 months (47\%) has anemia: 20\% in mild form, $25 \%$ with moderate form and $2 \%$ have severe anemia. From the point of view of age, it is between 6 and 17 months that children are most affected by anemia with a prevalence varying between $51 \%$ (minimum) at $12-17$ months and 59\% (maximum) at $6-8$ months. Although anemia can also be caused by parasitic infections, hemorrhages, congenital conditions or chronic diseases, it is most often caused by a food deficiency, including iron deficiency [12].

The approaches previously discussed have clearly shown that anemia is related to a nutritional iron deficiency, but it can also be a consequence of a chronic deficiency since neonatal period due to antenatal behaviors of mothers. Assumani et al. in 2018 in a study on the blood count of newborns of Lubumbashi, show that erythrocyte markers values were weak in its African population compared to the European population. The hypothesis was to know if there is a link between iron deficiency and mothers' behaviors during pregnancy, with ethnic origin and/or to genetic factors [13].

At birth, the reserve of iron is estimated by ferritin that is usually high to widely cover the needs of the chemosynthesis [14] [15] [16] [17]. In this context, an assay of the ferritin serum is a major advantage to highlight the relationship between erythrocytes markers and the rate of iron serum. So therefore, this study was aimed to determine the reference value of serum ferritin mother and newborn in the first 24 hours after birth, and to establish the link between these values.

\section{Materials and Methods}

\subsection{Study Framework}

The study was carried out in 10 health facilities, namely: the University Clinics of Lubumbashi, the Jason Sendwe hospital, the HGR Kenya, the Maternity Sainte Bernadette, the Health Center Maman wa Huruma, the Health Center Mery center, the Health Center Kenya 1, the Health Center Imani Bishop Nsolotshi and the AENEF. The selection of structures for data collection was made by reasoned choice, taking into account the following:

- welcome at least 300 newly pregnant women per year for prenatal consultations and for prenatal care;

- be accessible to all social strata of the population;

- ensuring deliveries;

- have a PMTCT service for the management of HIV infection. 


\subsection{Type of Study}

We carried out a descriptive cross-sectional study with an analytical component, covering the period from April 10 to July 17, 2019.

\subsection{Study Population and Sampling}

The population study was made by the mother and newborn couples. Our sample was exhaustive.

\subsubsection{Inclusion Criteria}

Were included in our study; the mother and newborn couple, according to the following criteria:

- mother who freely consented to participate in the study and who did not experience bleeding from the third trimester of pregnancy;

- newborn with normal weighted futures, from a large is singleton, no history of transfusion and having no pathology involving life-threatening.

\subsubsection{Criteria for Non-Inclusion}

1) For the mother

Icteric, sickle cell or thalassemic mother, cesarized, multiple birth, positive TPM and anti-tuberculosis, recently transfused (less than 4 months), antimitotic, with large spleen and/or large liver, febrile, CRP positive.

2) For the newborn

Icteric Newborn, polymarformed, or with infectious stigma (sepsis), fetomaternal $\mathrm{ABO}$ and/or Rh incompatibility, recently transfused newborn with depressed APGAR, with iron supplementation, sick at the time of selection, positive CRP.

\subsection{Study Parameters or Variables}

\subsubsection{For Mothers}

- Age (years);

- Marital status (living alone or living as a couple);

- Professional activity (activity generating revenue or not regenerating revenue);

- Parity: nulliparous (Po), primiparous (P1), pauciparous (P2-3) and multiparous $(\mathrm{P} \geq 4)[18]$;

- Nutritional status: appreciation indicator: brachial perimeter (BP): poor nutritional status: $\mathrm{BP}<24 \mathrm{~cm}$, good nutritional status: $\mathrm{BP} \geq 24 \mathrm{~cm}$ [19] [20] [21];

- Level of study: Low, if it is less than or equal to 8 years of study (2nd of secondary school); Acceptable if more than 8 years of study [22];

- Iron supplementation during pregnancy: yes or no;

- Tea consumption during pregnancy: yes or no;

- Kaolin consumption during pregnancy: yes or no.

\subsubsection{For Newborns}

- Gestational age (SA); 
- Weight (grams);

- Gender: female and male;

- Size $(\mathrm{cm})$;

- Head circumference $(\mathrm{cm})$;

- Thorax perimeter $(\mathrm{cm})$.

\subsubsection{Erythrocyte and Biochemical Parameters (Mothers and} Newborns)

- Hemoglobin (Hb) level: g/dl;

- Reticulocyte rate: \%;

- Average Globular Volume (VGM);

- Average Corpuscular Hemoglobin Concentration (CCMH): g/dl;

- Serum ferritin: $\mu \mathrm{g} / \mathrm{l}$

- Reactive Protein C (CRP): assay carried out by the qualitative and semi-quantitative method. CRP considered positive if greater than or equal to $6 \mathrm{mg} / \mathrm{l}$

The blood sample was taken on an empty stomach at the crease of the elbow, the tourniquet being weakly tight. The assay was carried out according to the methods recommended by the International Federation of Clinical Chemistry (IFCC) and by the International Council by Standardization in Heamotology (ICSH). We used the chemical PLC AU480 Beckman counter for assaying ferritin and CRP. And the SYSMEX KX21N hematology machine for the determination of erythrocyte markers. The serum ferritin assay was coupled with CRP in order to eliminate cases of acute inflammatory syndrome which could influence ferritinemia.

\subsection{Data Analysis}

The data processing was carried out using Epi Info 7.2.2.6 and SPSS version 23.0 software. The hemogram and ferritin values found were transformed to standard values using Z-Score to allow the values not included in the range of -2 DS and +2 DS to be located and the reference values are defined in this study as values between the 2.5th and 97.5th percentile.

Descriptive statistics made it easier for us to calculate frequencies, averages and standard deviations. The Mann-Whitney test was used to compare the means of two groups and the Rho Spearman correlation coefficient for the relationships between the parameters of the mother and those of the newborn. $\mathrm{p}<$ 0.05 was significative threshold is statistical. The study had respected the rules of confidentiality, justice and beneficence of mother-newborn couples.

The protocol for this research study was submitted and approved by the Department of Pediatrics and the Ethics Committee with the approval number: UNILU/CEM/094/2018.

\subsection{Limitations of the Study}

Although we have coupled the serum ferritin assay to CRP to eliminate cases of 
inflammatory syndrome that can influence ferritinemia, the intra-individual biological variability linked to very low serum ferritin levels can generate a bias. Hence the need, firstly, the soluble receptor assay of transferrin that we have not been able to achieve for lack of reagents and their high costs and, on the other hand, the dosage of the spinal cord ferritin, on the other hand, is an invasive method.

\subsection{Ethical Considerations}

Prior consent to all participants (mothers of newborn included), after clearly explained the purpose of the study has been obtained. The respect on confidentiality has been respected.

\section{Results}

\subsection{Sociodemographic Characteristics of the Mother}

The variables sociodemographic taken are in Table 1 reported that 76 mothers or $73.79 \%$ were aged from 20 - 35 years. The average age is $27.68 \pm 6.42$ years with such extreme 16 and 42 years. Regarding marital status, 101 mothers or $98.06 \%$ lived in a couple against only 2 or $1.94 \%$ who lived alone. In connection with the profession of a woman two had a professional regenerative recipe. Furthermore, the level of education was acceptable (78.64\%). As for parity, $49.50 \%$ of pregnant women were multiparous with an intergenic space beyond 24 months in $44.70 \%$ of cases. Iron supplementation was made in $19.40 \%$ of cases, the consumption of tea and Kaolin were respectively observed in $85.40 \%$ and $84.50 \%$ of cases. The majority of mothers had good nutritional status $(79.61 \%)$.

\subsection{Parameters Related to Newborns}

\subsubsection{Sex}

Figure 1 reports 58 female newborns, or 56.3\%. The sex ratio Male/Female was 0.77 for females.

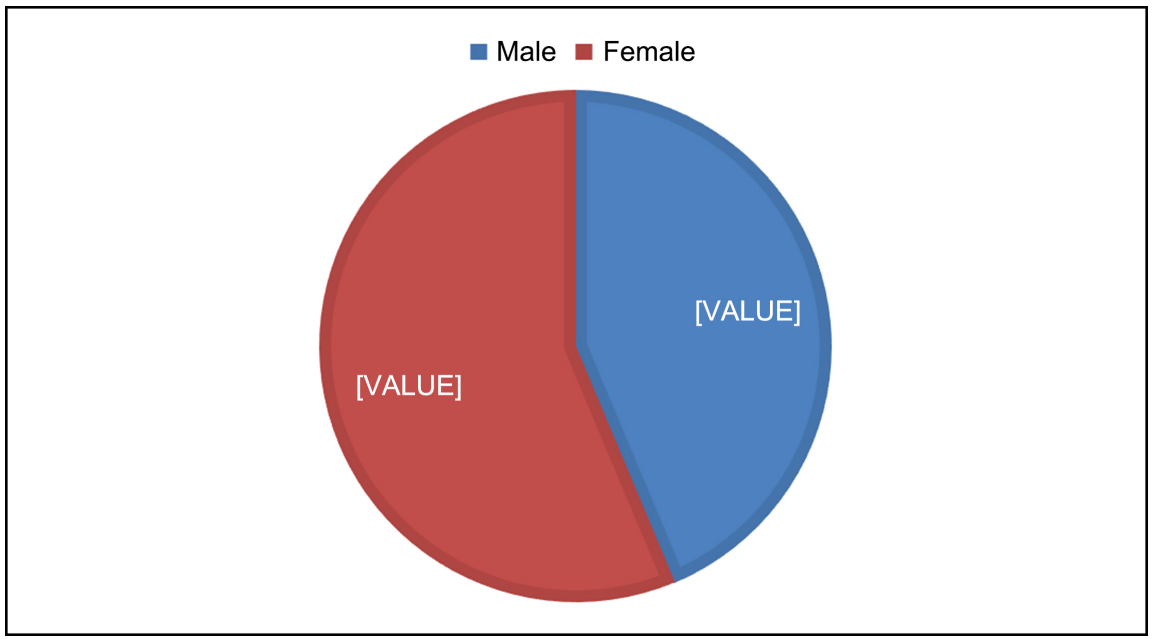

Figure 1. Sex of the newborn. 
Table 1. Sociodemographic characteristics of the mother.

\begin{tabular}{|c|c|c|c|}
\hline Age (years) & $\begin{array}{l}\text { Workforce } \\
(n=103)\end{array}$ & Percentage & $M \pm S D$ \\
\hline$<20$ & 10 & 9.71 & $27.68 \pm 6.42$ \\
\hline $20-35$ & 76 & 73.79 & \\
\hline$>35$ & 17 & 16.50 & \\
\hline \multicolumn{4}{|l|}{ Marital status } \\
\hline Living alone & 2 & 1.94 & \\
\hline Living as a couple & 101 & 98.06 & \\
\hline \multicolumn{4}{|l|}{ Profession } \\
\hline Recipe regenerator & 53 & 51.46 & \\
\hline Non-regenerative of recipes & 50 & 48.57 & \\
\hline \multicolumn{4}{|l|}{ Study level } \\
\hline Low & 22 & 21.36 & \\
\hline Acceptable & 81 & 78.64 & \\
\hline \multicolumn{4}{|l|}{ Parity } \\
\hline Primiparous $(\mathrm{p}=1)$ & 21 & 20.40 & \\
\hline Pauciparous (p $2-3$ ) & 31 & 30.10 & \\
\hline Multipar ( $\mathrm{p} \geq 4$ ) & 51 & 49.50 & \\
\hline \multicolumn{4}{|l|}{ Intergenerational space (months) } \\
\hline$<12$ & 18 & 17.50 & \\
\hline $12-24$ & 31 & 30.10 & \\
\hline$>24$ & 46 & 44.70 & \\
\hline Not precise & 8 & 7.80 & \\
\hline \multicolumn{4}{|l|}{ Nutritional status } \\
\hline Bad & 21 & 20.39 & \\
\hline Well & 82 & 79.61 & \\
\hline \multicolumn{4}{|l|}{ Iron supplementation } \\
\hline No & 83 & 80.60 & \\
\hline Yes & 20 & 19.40 & \\
\hline \multicolumn{4}{|l|}{ Kaolin consumption } \\
\hline No & 15 & 14.60 & \\
\hline Yes & 88 & 85.40 & \\
\hline \multicolumn{4}{|l|}{ Tea consumption } \\
\hline No & 16 & 15.50 & \\
\hline Yes & 87 & 84.50 & \\
\hline
\end{tabular}




\subsubsection{Gestational Age and Anthropometric Parameters of the Newborn}

As shown in Table 2, the mean gestational age was $39.67 \pm 1.26$ weeks. The anthropometric parameters of the newborn varied as follows: the weight 3065.58 $\pm 433.83 \mathrm{~g}$, the size $48.17 \pm 1.91 \mathrm{~cm}$, the cranial perimeter $34.80 \pm 1.14 \mathrm{~cm}$, the perimeter thoracic $33.19 \pm 1.62 \mathrm{~cm}$, the upper arm $10.84 \pm 1.05 \mathrm{~cm}$. It was observed that only the weight exhibited a fairly large variability.

\subsection{Erythrocyte Parameters and Organic Chemicals from the Mother and Newborn}

As shown in Table 3, the biological parameters of the mother give a mean serum ferritin $59.21 \pm 48.09 \mathrm{mg} / \mathrm{l}$ with high variability (81.22) compared to that of the newborn is of $290.18 \pm 212.69 \mu \mathrm{g} / \mathrm{l}$ with fairly low variability (73.29).

\subsection{Reference Values Erythrocyte and Organic Chemicals from the Mother and Newborn}

As shown in Table 4, reference values of serum ferritin in the mother vary from 21.10 to $114.00 \mathrm{~g} / \mathrm{l}$ and in the newborn, it varies from 60.99 to $749.01 \mathrm{~g} / \mathrm{l}$.

\subsection{Correlation Parameters Erythrocyte and Organic Chemicals from Mother}

As shown in Table 5, the matrix of correlation of mother's biological parameters

Table 2. Gestational age and anthropometric parameters of newborns.

\begin{tabular}{cccc}
\hline Parameters & N & Average & Coefficient of variation \\
\hline Gestational age (SA) & 103 & $39.67 \pm 1.26$ & 3.17 \\
Weight $(\mathrm{g})$ & 103 & $3065.58 \pm 433.83$ & 14.15 \\
Height $(\mathrm{cm})$ & & $48.17 \pm 1.91$ & 3.97 \\
Head circumference $(\mathrm{cm})$ & 103 & $34.80 \pm 1.14$ & 3.28 \\
Thoracic perimeter $(\mathrm{cm})$ & 103 & $33.19 \pm 1.62$ & 4.88 \\
Brachial perimeter $(\mathrm{cm})$ & 103 & $10.84 \pm 1.05$ & 9.69 \\
\hline
\end{tabular}

Table 3. Mean and standard deviation of erythrocyte parameters and organic chemicals from the mother and newborn.

\begin{tabular}{cccccc}
\hline Parameters & N & Mother & $\begin{array}{c}\text { Coefficient of } \\
\text { the variation }\end{array}$ & Newborn & $\begin{array}{c}\text { Coefficient of } \\
\text { variation }\end{array}$ \\
\hline Hemoglobin level (g/dl) & 103 & $10.16 \pm 1.47$ & 14.47 & $17.28 \pm 2.27$ & 13.14 \\
VGM (fl) & 103 & $84.70 \pm 8.35$ & 9.86 & $96.28 \pm 21.98$ & 22.83 \\
CCMH (g/dl) & 103 & $28.82 \pm 2.18$ & 7.56 & $30.2 \pm 2.40$ & 7.82 \\
Reticulocytes (\%) & 103 & $0.86 \pm 0.29$ & 33.72 & $1.11 \pm 0.39$ & 7.82 \\
Serum ferritin ( $\mu \mathrm{g} / \mathrm{l})$ & 103 & $59.21 \pm 48.09$ & 81.22 & $290.18 \pm 212.69$ & 73.29 \\
\hline
\end{tabular}


shows a positive and significant correlation $(0.216 ; \mathrm{p}=0.029)$ between the hemoglobin and the rate of MCHC. A positive and very significant correlation $\left(0.270^{* *} ; p=0.006\right)$ between reticulocytes and CCMH. Furthermore, the non-significant negative correlation $(-0.131 ; \mathrm{p}=0.186)$ between the hemoglobin level and the reticulocytes and a non-significant positive correlation $(0.156 ; \mathrm{p}=$ 0.426 ) between the reticulocyte level and the serum ferritin.

\subsection{Correlation Parameters Erythrocyte and Organic Chemicals in the Newborn}

As shown in Table 6, the correlation matrix of newborn's biological parameters reported a positive correlation and very significant $(0.288, \mathrm{p}=0.003)$ between the hemoglobin and ferritin. A significant positive and t correlation $(0.205 ; \mathrm{p}=$ 0.037) between the hemoglobin level and the CCMH.

\subsection{Correlation Parameters Erythrocyte and Organic Chemicals in Infants (Newborn) and Ferritin Mother}

As shown in Table 7, the correlation matrix of s parameter s erythrocyte newborn and maternal ferritin shows a correlation positive and significant $(0.191, \mathrm{p}$ $=0.037$ ) between the baby MCV and ferritin maternal serum.

Table 4. Values references erythrocyte and organic chemicals from the mother and newborn.

\begin{tabular}{cccc}
\hline Setting & N & Mother & Newborn \\
\hline Rate of hemoglobin (g/d) & 103 & 6.96 to 12.29 & 12.90 to 21.40 \\
VGM (fl) & 103 & 69.22 to 97.11 & 24.10 to 114.13 \\
CCMH (g/dl) & 103 & 24.90 to 32.66 & 24.10 to 33.80 \\
Reticulocytes (\%) & 103 & 0.60 to 1.60 & 0.60 to 2.00 \\
Serum ferritin $(\mu \mathrm{g} / \mathrm{l})$ & 103 & 21.10 to 114.00 & 60.99 to 749.01 \\
\hline
\end{tabular}

Table 5. Correlation parameters erythrocyte and organic chemicals from mother.

\begin{tabular}{cccccc}
\hline & $\begin{array}{c}\text { Rate of } \\
\text { hemoglobin } \\
(\mathrm{g} / \mathrm{dl})\end{array}$ & VGM $(\mathrm{fl})$ & $\begin{array}{c}\text { CCMH } \\
(\mathrm{g} / \mathrm{dl})\end{array}$ & $\begin{array}{c}\text { Reticulocytes } \\
(\%)\end{array}$ & $\begin{array}{c}\text { Serum } \\
\text { ferritin }\end{array}$ \\
\hline Hemoglobin level (g/d) & & 0.185 & 0.029 & 0.186 & 0.426 \\
VGM (fl) & 0.132 & & 0.652 & 0.713 & 0.473 \\
CCMH (g/dl) & $0.216^{*}$ & -0.045 & & 0.006 & 0.071 \\
Reticulocytes $(\%)$ & -0.131 & -0.037 & $0.270^{* *}$ & & 0.115 \\
Serum ferritin $(\mu \mathrm{g} / \mathrm{l})$ & 0.079 & 0.071 & 0.042 & 0.156 &
\end{tabular}

${ }^{*}$ The correlation is significant at the 0.01 level (bilateral); ${ }^{*}$ The correlation is significant at the 0.05 level (bilateral). 
Table 6. Correlation parameters erythrocyte and organic chemicals in the newborn.

\begin{tabular}{cccccc}
\hline Correlation & $\begin{array}{c}\text { Serum } \\
\text { ferritin }\end{array}$ & $\begin{array}{c}\text { Rate of } \\
\text { hemoglobin } \\
(\mathrm{g} / \mathrm{dl})\end{array}$ & VGM (fl) & $\begin{array}{c}\text { CCMH } \\
(\mathrm{g} / \mathrm{dl})\end{array}$ & $\begin{array}{c}\text { Reticulocytes } \\
(\%)\end{array}$ \\
\hline Serum ferritin & & 0.003 & 0.753 & 0.106 & 0.929 \\
Hemoglobin level (g/dl) & $0.288^{* *}$ & & 0.699 & 0.037 & 0.686 \\
VGM (fl) & 0.031 & 0.039 & & 0.871 & 0.375 \\
CCMH (g/dl) & 0.160 & $0.205^{*}$ & -0.016 & & 0.800 \\
Reticulocytes (\%) & 0.009 & -0.040 & 0.088 & 0.025 & \\
\hline
\end{tabular}

${ }^{*}$ The correlation is significant at the 0.01 level (bilateral); ${ }^{\star}$ The correlation is significant at the 0.05 level (bilateral).

Table 7. Correlation parameters erythrocyte and organic chemical in infants (n-born) and ferritin mother.

\begin{tabular}{ccccccc}
\hline Correlation & $\begin{array}{c}\text { Maternal } \\
\text { ferritin }\end{array}$ & $\begin{array}{c}\text { Ferritin } \\
\text { newborn }\end{array}$ & $\begin{array}{c}\text { N-born } \\
\text { hemoglobin }\end{array}$ & $\begin{array}{c}\text { VGM } \\
\text { newborn }\end{array}$ & $\begin{array}{c}\text { CCMH } \\
\text { newborn }\end{array}$ & $\begin{array}{c}\text { Reticulocytes } \\
\text { No baby }\end{array}$ \\
\hline Maternal ferritin & & 0.917 & 0.808 & 0.037 & 0.707 & 0.823 \\
Ferritin n-born & -0.010 & & 0.011 & 0.538 & 0.316 & 0.876 \\
N-born hemoglobin & 0.022 & $0.231^{*}$ & & 0.860 & 0,020 & 0.552 \\
VGM born & $0.191^{*}$ & 0.057 & 0.016 & & 0.531 & 0.574 \\
CCMH n-born & -0.035 & 0.092 & $0.212^{*}$ & -0.058 & & 0.349 \\
Baby reticulocytes & -0.021 & -0.014 & -0.055 & 0.052 & 0.086 & \\
\hline
\end{tabular}

\subsection{Iron Supplementation during Pregnancy in the Mother, Erythrocyte Parameters and Ferritin in the Newborn}

As shown in Table 8, iron supplementation in mothers in the third quarter brought a slight Amelio ration red cell parameters of the new-born but not significant for most except for hemoglobin for which the difference is statistically significant $(\mathrm{p}=0.020)$.

\subsection{Tea Consumption during Pregnancy in the Mother, Erythrocyte Parameters and Ferritin in the Newborn}

As shown in Table 9, the consumption of tea in the mother, although not statistically significant, a tendency to decrease the erythrocyte values in newborn.

\subsection{Consumption of Kaolin during Pregnancy in the Mother, Erythrocyte Parameters and Ferritin of the Newborn}

Kaolin consumption in the mother, although not statistically significant, is a tendency to decrease the biological values of the new-born (Table 10). 
Table 8. Iron supplementation in the mother and in erythrocyte ameters of the newborn.

\begin{tabular}{cccc}
\hline \multirow{2}{*}{ Parameters } & \multicolumn{2}{c}{ Iron supplement } & \multirow{2}{*}{ p-value } \\
\cline { 2 - 3 } & Yes $(\mathrm{n}=20)$ & No $(\mathrm{n}=83)$ & \\
\hline Hemoglobin level $(\mathrm{g} / \mathrm{dl})$ & $18.23 \pm 1.87$ & $16.86 \pm 2.29$ & $0.020^{*}$ \\
VGM (fl) & $82.91 \pm 29.51$ & $94.26 \pm 19.75$ & 0.210 \\
CCMH (g/dl) & $30.48 \pm 2.88$ & $30.64 \pm 2.29$ & 0.854 \\
Reticulocytes $(\%)$ & $1.05 \pm 0.35$ & $1.04 \pm 0.40$ & 0.954 \\
Ferritin $(\mu \mathrm{g} / \mathrm{l})$ & $285.67 \pm 197.29$ & $205.85 \pm 215.69$ & 0.253 \\
\hline
\end{tabular}

${ }^{*} \mathrm{P}$-value is significantly less than 0.05 .

Table 9. Consumption of tea at the mother, erythrocyte ferritin parameters and newborn.

\begin{tabular}{cccc}
\hline \multirow{2}{*}{ Parameters } & \multicolumn{2}{c}{ Tea } & p-value \\
\cline { 2 - 3 } & Yes $(\mathrm{n}=21)$ & No $(\mathrm{n}=82)$ & 0.916 \\
Vemoglobin level (g/dl) & $17.29 \pm 2.34$ & $17.22 \pm 1.91$ & 0.949 \\
CCMH (gl) & $97.00 \pm 22.36$ & $96.62 \pm 20.50$ & 0.391 \\
Reticulocytes (\%) & $30.80 \pm 2.34$ & $30.23 \pm 2.74$ & 0.662 \\
Ferritin $(\mu \mathrm{g} / \mathrm{l})$ & $1.12 \pm 0.41$ & $1.07 \pm 0.24$ & 0.885 \\
\hline
\end{tabular}

Table 10. Consumption of Kaolin during pregnancy in the mother, erythrocyte parameters and ferritin in the newborn.

\begin{tabular}{cccc}
\hline \multirow{2}{*}{ Settings } & \multicolumn{2}{c}{ Kaolin } & \multirow{2}{*}{ p-value } \\
\cline { 2 - 3 } & No $(\mathrm{n}=15)$ & Yes $(\mathrm{n}=88)$ & 0.607 \\
VGM (fl) & $17.00 \pm 1.54$ & $17.32 \pm 2.37$ & 0,352 \\
CCMH (g/dl) & $101.86 \pm 6.19$ & $96.11 \pm 23.57$ & 0.292 \\
Reticulocytes (\%) & $30.10 \pm 2.59$ & $30.81 \pm 2.37$ & 0.348 \\
Ferritin $(\mu \mathrm{g} / \mathrm{l})$ & $1.02 \pm 0.35$ & $1.12 \pm 2.37$ & 0.886 \\
\hline
\end{tabular}

\section{Discussion}

\subsection{Sociodemographic Features of Mothers}

The sociodemographic profile in Table 1 reported that 76 mothers or $73.79 \%$ were aged from 20 - 35 years. The average age was $27.68 \pm 6.42$ years with 16 and 42 as the extreme. A study in France reported that out of 57 patients in the study, the average age was $27.6 \pm 0.7$ years [23]. These results are slightly lower than those of Assumani et al. in Lubumbashi, which have found a mean age of 
$29.9 \pm 5.7$ ans [13]

Regarding marital status, in our series the majority of mothers lived in a couple $(98.06 \%)$, one in two mothers had a profession generating revenue. The most was the level of study acceptable (64\%). These results are major part superimposable to those of Assumani et al. [13]. In relation to parity, 49.50\% of cases, our pregnant women were multiparous, this result is similar to Assumani et al. [13] who reported more multiparous. Since, the profile of the mother in Lubumbashi has not changed as found in our study. Audrey Camizuli in France [23] reported a significant proportion of primiparous patients $(45.6 \%)$.

\subsection{Gestational Age and Anthropometric Parameters of the Newborn}

In our series, the average gestational age was $39.67 \pm 1.26 \mathrm{~S} \mathrm{~A}$ and the anthropometric parameters of the newborn varied as follows: weight $3065.58 \pm 433.83$ $\mathrm{g}$, size $48.17 \pm 1.91 \mathrm{~cm}$, the cranial perimeter $34.80 \pm 1.14 \mathrm{~cm}$, the thoracic perimeter $33.19 \pm 1.62 \mathrm{~cm}$, the brachial perimeter $10.84 \pm 1.05 \mathrm{~cm}$. It was observed that only the weight exhibited quite significant variability. The parameters remained superimposable on those of Assumani et al. [13], and within the limits of evolution as described by the Alexander scales [24].

\subsection{Average and Range of Reference Values of Erythrocytes in Mother and Newborn}

The mean serum ferritin in mothers is $59.21 \pm 48.09 \mathrm{mg} / \mathrm{l}$ with high variability (81.22) compared to newborn which is $290.18 \pm 212.69 \mathrm{mcg} / \mathrm{l}$ with fairly low variability (73.29).

Ferritin crumb undergoes important variations during the first-year service life. Our results can be superimposed on those of Morel et al. [25] that in turn the first months have observed an average $254.4 \mathrm{mg} / \mathrm{l}$. Unlike the study by Sankande et al., in Ivory Coast who reported a low ferritin level of $116.20 \pm 105.95$ $\mu \mathrm{g} / \mathrm{l}$ but which remains grafted with high variability [26]. The values of the newborn are much higher than adults references in our series which is at odds with previous work that reported levels in the newborn in terms of the order of $100 \mu \mathrm{g} / \mathrm{l}$ and peaking in the first month at $350 \mu \mathrm{g} / 1$ [27].

The concentration serum in ferritin showed strong variability which shows a wide dispersion of values in ferritin from birth, most of which are in the normal range compared with the values of the European.

The reference values of serum ferritin in the mother vary from $21.10-114.00$ $\mu \mathrm{g} / \mathrm{l}$ and in the newborn, it varies from $60.99-749.01 \mu \mathrm{g} / \mathrm{l}$. These values can be superimposed on those of Maachi et al. who reported a reference interval ranging from 50 to $600 \mu \mathrm{g} / \mathrm{l}$ the serum ferritin concentration in the newborn [4]. However, through various studies on the iron status of the newborn, the authors observed averages ranging from 81 to $677 \mathrm{mg} / \mathrm{l}$ for ferritin serum [16] [17] [28] [29] [30]. 
Red cell markers, such as hemoglobin, the mean corpuscular volume, concentration corpuscular average hemoglobin and reticulocytes exhibited values comparable reference to those of Assumani [13], contrary to Sakande et al. who reported very low values [26]. By comparing the mother to the newborn; All markers were increased in the normal range in the newborn. These results are in agreement with those of the literature [31]

\subsection{Correlation Matrix Parameters Erythrocyte in the Mother and in the Newborn}

The correlation matrix parameters erythrocyte mother shows a positive and significant correlation $(0.216 ; p=0.029)$ between the hemoglobin and the rate of MCHC. A positive and very significant correlation $\left(0.270^{* *} ; \mathrm{p}=0.006\right)$ between reticulocytes and CCMH. Furthermore, the non-significant negative correlation $(-0.131 ; \mathrm{p}=0.186)$ between the hemoglobin level and the reticulocytes and a non-significant positive correlation $(0.156 ; \mathrm{p}=0.426)$ between the reticulocyte level and the serum ferritin.

The newborn's biological correlation matrix parameter reported a positive correlation and very significant $(0.288, \mathrm{p}=0.003)$ between the hemoglobin and ferritin. A positive and significant correlation $(0.205 ; p=0.037)$ between the hemoglobin level and the CCMH. We observed a non-significant positive correlation $(0.160 ; \mathrm{p}=0.106)$ between serum ferritin and $\mathrm{CCMH}$.

The two-matrix shows that maternal serum concentration of ferritin is not bound to any parameters of iron status. In the newborn the ferritin is closely related to hemoglobin. These results corroborate with this stream of Dop et al. in Lomé [32] and Sakande et al. [26] in Ivory Coast. The authors thought that the lack of correlation between the hemoglobin level of mothers and newborns testifies to the active transfer of iron to the fetus. However, when the maternal serum iron is low, it no longer allows sufficient supplies to the fetus whose serum iron is then reduced.

\subsection{Iron Supplementation in the Mother and Erythrocyte Parameters in the Newborn}

In our series, iron supplementation in the mother in the third trimester brings a slight improvement in erythrocyte parameters of the newborn but not significant for most, except the hemoglobin level for which the difference is statistically significant $(\mathrm{p}=0.020)$. The intake of iron during pregnancy has been shown as an effective way to fight against iron deficiency. The authors: Assumani et al. [13] and Dop et al. [32] have also dice showed.

\subsection{Consumption of Tea, Kaolin in the Mother and Biological Parameters of the Newborn}

The consumption of tea and the kaolin in the mother, although statistically insignificant, has the negative influence on the future of ferritin and markers eryt- 
hrocyte newborn. These results corroborate those of a study carried out by WHO in 2012 [10] and by Assumani [13] who made the same observation.

\section{Conclusion}

The mother-newborn Lubumbashi has a rate of ferritin in serum within accepted standards. To better understand the origins of deficient anemia of the newborn within 24 hours of birth in our environment, we suggest that we consider as reference values of serum ferritin, those in the interval [60.99 - 749.01 $\mu \mathrm{g} / \mathrm{l}]$. Although weak and not statistically significant, there is a negative correlation between maternal serum ferritin and that of the newborn.

\section{Acknowledgments}

The authors sincerely thank the laboratory managers of the Sendwe General Reference hospital for the allotment of the samples and Dee Services for the processing and reading of our samples.

\section{Author Contributions}

All the authors contributed to the realization of this work; they read and approved the final version of the manuscript.

\section{Conflicts of Interest}

The authors declare no conflicts of interest regarding the publication of this paper.

\section{References}

[1] Debril, J.-C. (2007) La prise en Charge des Surcharges en fer. Université Henri Poincaré, Nancy.

[2] Dézier, J.F. and Vernet, M. (1992) Détermination de la Ferritine Sérique: Intérêt et Limites. La Presse Médicale, 21, 1283-1286.

[3] Withold, W., Neumayer, C., Beyrau, R., Heins, M., Schauseil, S. and Rick, W. (1994) Efficacy of Transferrin Determination in Human Sera in the Diagnosis of Iron Deficiency. Clinical Chemistry and Laboratory Medicine, 32, 19-25. https://doi.org/10.1515/cclm.1994.32.1.19

[4] Maachi, M., Fellahi, S., Puy, H. and Bastard, J.-P. (2005) Difficultés d’Interprétation d'un Résultat de Ferritine en 2004. Revue Française des Laboratoires, 2005, 21-24. https://doi.org/10.1016/S0338-9898(05)80161-1

[5] Mario, N. and Pernet, P. (2007) Quels Marqueurs Pour le Bilan Martial? Spectra Analyse, 26, 48-53.

[6] Vernet, M. (1989) Ferritine: Aspects Techniques, Place de cet Examen dans l'Exploration du Métabolisme du fer et dans Diverses Pathologies. Feuillets de Biologie, 30, 35-42.

[7] Musimwa, A.M., Kitoko, H.T., Wakamb, G.K., Okitotsho, S.W. and Numbi, O.L. (2018) Concentration sérique en fer au cours de la Malnutrition chez l'enfant: Cas d'une Zone Urbaine et Rurale en République Démocratique Congo. Pan African Medical Journal, 31, Article No. 55. https://doi.org/10.11604/pamj.2018.31.55.16089 
[8] Krebs, N.F. (2000) Dietary Zinc and Iron Sources, Physical Growth and Cognitive Development of Breastfed Infants. The Journal of Nutrition, 130, 358S-360S. https://doi.org/10.1093/jn/130.2.358S

[9] Diouf, S., Folquet, M., Mbofung, K., Ndiaye, O., Brou, K., Dupont, C., et al. (2015) Prévalence et Déterminants de l'anémie chez le Jeune enfant en Afrique Francophone-Implication de la Carence en fer. Archives de Pédiatrie, 22, 1188-1197. https://doi.org/10.1016/j.arcped.2015.08.015

[10] Organisation Mondiale de la Santé (2012) Directive: Supplémentation Intermittente en fer Chez les Enfants d'âge Préscolaire et Scolaire. Organisation Mondiale de la Santé, Geneva.

[11] Kalenga, M.-K., Nyembo, M.-K., Nshimba, M. and Foidart, J.-M. (2008) Étude de l'anémie chez les Femmes Enceintes et les Femmes Allaitantes de Lubumbashi (République Démocratique du Congo). Journal de Gynécologie Obstétrique et Biologie de la Reproduction, 32, 647-653.

[12] Ministère du Plan et Suivi de la Mise en œuvre de la Révolution de la Modernité, Ministère de la Santé Publique and ICF International (2014) Enquête Démographique et de Santé en République Démocratique du Congo 2013-2014. Ministère du Plan et Suivi de la Mise en œuvre de la Révolution de la Modernité, Ministère de la Santé Publique, ICF International, Rockville.

[13] Assumani, A.N., Gini, J.L., Nkodila, A., Kanteng, G., Wembonyama, S.O., Tambwe, A., et al. (2018) Evaluation de l'hémogramme du Nouveau-né de Lubumbashi: Étude Transversal Multicentrique (à propos de 430 cas). Revue de PInfirmier Congolais, 2, 95-102.

[14] Diagne, I., Archambeaud, M.P., Diallo, D., D’oiron, R., Yvart, J. and Tchernia, G. (1995) Paramètres érythrocytaires et réserves en fer dans le Sang du Cordon. Archives de Pédiatrie, 2, 208-214. https://doi.org/10.1016/0929-693X(96)81129-8

[15] Diallo, D., Archambeaud, M.P., Yvart, J. and Tchernia, G. (1990) La Ferritine érythrocytaire chez le Nouveau-né Humain. In: Hercberg, S., Galan, P. and Dupin, Eds., H., Eds., Aspects Actuels des Carences en fer dans le Monde: Colloque International, Vol. 197, Institut National de la Santé et de la Recherche Médicale, Paris, 185-192.

[16] Liappis, N. and Schlebusch, H. (1990) Reference Values of the Ferritin Concentration in the Serum in Children. Klinische Pädiatrie, 202, 99-102.

https://doi.org/10.1055/s-2007-1025496

[17] Milman, N., Ibsen, K.K. and Christensen, J.M. (1987) Serum Ferritin and Iron Status in Mothers and Newborn Infants. Acta Obstetricia et Gynecologica Scandinavica, 66, 205-211.

[18] Nahar, N., Afroza, S. and Hossain, M. (1998) Incidence of Low Birth Weight in Three Selected Communities of Bangladesh. Bangladesh Medical Research Council Bulletin, 24, 49-54.

[19] Krasovec, K. and Anderson, M.A. (1991) Maternal Nutrition and Pregnancy Outcomes: Anthropometric Assessment. Pan American Health Organization, Washington DC.

[20] Meda, N., Soula, G., Dabis, F., Cousens, S., Some, A., Mertens, T., et al. (1995) Facteurs de Risque de Prématurité et de Retard de Croissance Intra-Utérin au Burkina Faso. Revue d Epidémiologie et de Santé Publique, 43, 215-224.

[21] Karim, E. and Mascie-Taylor, C.G.N. (1997) The Association between Birthweight, Sociodemographic Variables and Maternal Anthropometry in an Urban Sample from Dhaka, Bangladesh. Annals of Human Biology, 24, 387-401. 
https://doi.org/10.1080/03014469700005152

[22] Elshibly, E.M. and Schmalisch, G. (2008) The Effect of Maternal Anthropometric Characteristics and Social Factors on Gestational Age and Birth Weight in Sudanese Newborn Infants. BMC Public Health, 8, Article No. 244. https://doi.org/10.1186/1471-2458-8-244

[23] Camizuli, A. (2014) Prise en compte du VGM, de la CCMH et de la Ferritinémie dans le Diagnostic des Anémies Ferriprives Pendant la Grossesse: Étude Descriptive à la Maternité Lariboisière, Paris, Archive Ouverte HAL, dumas-01056895.

[24] Fescina, R.H. and Ucieda, F.J. (1980) Reliability of Fetal Anthropometry by Ultrasound. Journal of Perinatal Medicine, 8, 93-99. https://doi.org/10.1515/jpme.1980.8.2.93

[25] Morel, P., Guibourdenche, J. and Porquet, D. (1995) Détermination des Valeurs de Référence de la Ferritine Sérique en Pédiatrie à l'aide de l'Automate ACS 180. Immuno-analyse \& Biologie Spécialisée, 10, 285-290.

https://doi.org/10.1016/0923-2532(96)80538-2

[26] Sakande, J., Sawadogo, D., Nacoulma, E.W.C., Tiahou, G., Gnagne, A.C., Sess, E.D., et al. (2004) Métabolisme du fer et Valeurs érythrocytaires du Nouveau-né Ivoirien: Relation Avec le Statut en fer de la mère. Cahiers d'Études et de Recherches Francophones, 14, 17-20.

[27] Vermet, M. (1990) Ferritine. In: Siest, G., Henry, J. and Shiele, F., Eds., Référence en Biologie Clinique, Elsevier, Paris, 261-270.

[28] Celada, A., Busset, R., Gutierrez, J. and Herreros, V. (1982) Maternal and Cord Blood Ferritin. Helvetica Paediatrica Acta, 37, 239-244.

[29] Hussain, M.A., Gaafar, T.H., Laulicht, M. and Hoffebrand, A.V. (1977) Relation of Maternal and Cord Blood Serum Ferritin. Archives of Disease in Childhood, 52, 782-784. https://doi.org/10.1136/adc.52.10.782

[30] Wong, C.-T. and Sana, N. (1990) Inter-Relationships of Storage Iron in the Mother, the Placenta and the Newborn. Acta Obstetricia et Gynecologica Scandinavica, 69, 613-616. https://doi.org/10.3109/00016349009028705

[31] Georgieff, M.K., Wewerka, S.W., Nelson, C.A. and de Regnier, R.-A. (2002) Iron Status at 9 Months of Infants with Low Iron Stores at Birth. The Journal of Pediatrics, 141, 405-409. https://doi.org/10.1067/mpd.2002.127090

[32] Dop, M.-C., Blot, I., Dyck, J.-L., Assimadiw, K., Hodonouq, A.K.S. and Doh, A. (1992) L'anémie à l'Accouchement à Lomé (Togo): Prévalence, Facteurs de Risque et Répercussions chez le Nouveau-né. Revue d Epidémiologie et de Santé Publique, 40, 259-267. 